Tjalling C. Koopmans Research Institute

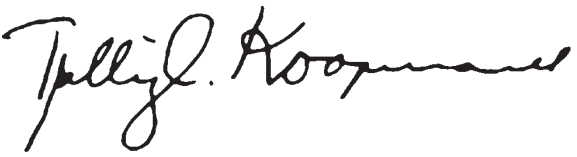

Discussion Paper Series nr: 08-18

\title{
Dancing with the Devil: A Study of Country Size and the Incentive to Tolerate Money Laundering
}

Hinnerk Gnutzmann Killian McCarthy

Brigitte Unger 
Utrecht School of Economics

Tjalling C. Koopmans Research Institute

Discussion Paper Series 08-18

\title{
Dancing with the Devil: A Study of Country Size and the Incentive to Tolerate Money Laundering
}

\author{
Hinnerk Gnutzmanna \\ Killian McCarthy \\ Brigitte Unger ${ }^{c}$ \\ ${ }^{a}$ European University Institute \\ Folrence, Italy \\ ${ }^{\mathrm{b}}$ Faculty of Economics \& Business \\ Rijksuniversiteit Groningen
}

'Utrecht School of Economics Utrecht University

August 2008

\begin{abstract}
The incidence of money laundering, and the zeal with which international anti-money laundering (AML) policy is pursued, varies significantly from country to country, region to region. There are, however, quite substantial social costs associated with a policy of toleration, and this begs the question as to why such variance should exist. In this paper we claim that, due to the globalisation of crime, if a single country should break the "chain of accountability", then it will provide a safe haven for criminals and attract the total financial proceeds of crime. Because smaller economies are best able to insulate themselves from the costs of crime, smaller countries therefore bear only a tiny share of the total costs relative to potential benefits of investment that money laundering offers, and so have a higher incentive to tolerate the practice compared to their larger neighbours. As such, we claim that the existence of a money laundering market is due to a policy of AML 'defection', and that the degree of 'defection' depends largely on the physical size of the country. In this paper we present a simple model of policy competition which formalises this intuition.
\end{abstract}

Keywords: Money Laundering; Policy Competition; Systems Competition

\section{Acknowledgements}

The first draft of this paper was created as part of the course 'Advanced Public Sector Economics', as offered by the Universiteit Utrecht School of Economics (June, 2007). A later draft was presented at the Tackling Money Laundering Conference (November 2007). The authors would like to thank Bas van Groezen and Loek Groot of the Universiteit Utrecht Chair of Public Sector Economics, Wilfred Dolfsma of the Rijksuniversiteit Groningen Chair of Innovation Management \& Strategy, as well as the many participants of the Tackling Money Laundering Conference for their helpful comments in the preparation of this, the final draft. All remaining errors remain the responsibility of the authors. 


\section{Introduction}

Variously defined as "deviant behaviour [which] violates the prevailing norms and cultural standards on how humans ought to behave", as a "public wrong" and as an exploit "injurious to the community" (Ormerod 2005), crime exists and crime endures because crime offers the individual an opportunity to gain. It is held to be "wrong" and "injurious" because these gains typically benefit the criminal far less then they cost society. Estimates, for example, place the total cost of crime to the US in the region of $\$ 1$ trillion per annum (Takats, 2007; Reuters \& Truman 2004; Anderson, 1999), and in the range of 50-60bn ( $\$ 95-115 \mathrm{bn})$ per annum in the UK (Brand \& Price, 2000; Audit Commission, 1999). By offering the individual an easy way out, however, crime provides the criminal with a cost effective source of power, influence and authority, and so - given that the "general inclination of all mankind [is] a perpetual and restless desire of power after power" (Hobbes 1651) - crime, it is easily recognised, is the unavoidable consequence of human ambition and creativity, and the flip-side of his entrepreneurial spirit.

Inevitable as it may be, society can tolerate only a minimal level of crime, and so is forced to 'tip the scales' in favour of legitimate activity with the criminilisation of all 'injurious' behaviour. In observing that crime is motivated by profit, 'balance' can be achieved through the manipulation of the profit formula; for example, by increasing the risks of capture, or the costs and severity of punishment (Ehrlich, 1973; Blumstein \& Nagin, 1977; Wolpin, 1978).

Such a rebalancing act is only possible if policy can be effectively imposed. In a world where the proceeds of crime are measured in the tens of billions (Rawlings \& Unger, 2008; Unger, 2007), and where the sheer complexity of the operations makes the risk of detection often too remote a possibility to act as a deterrent, many believe that traditional approaches are simply not sufficient. Many are therefore choosing to supplement these methods with the practice of institutionalised ostracism and are thus refusing the criminal, and his proceeds, access the legitimate economy. By doing so, these countries are denying the criminal the value of his money, the source of his power and prestige, and, consequently, they are attacking his very raison d'tre.

But desirable as this may sound, many uncomfortable questions are raised in the process regarding the substitutability of money (Unger,2007). By direct intention the distinction between 'legal' and 'illegal' monies means, of course, that a 'dirty dollar' earned in the criminal economy is worth less then one earned in the legitimate economy, and so the profitability of crime is reduced. Criminal incomes are effectively 'taxed' at a rate equal to the state's enthusiasm for a crime free society. Because crime already 'pays' less than the legitimate economy (Wilson \& Abrahamse, 1992), any loss in profitability implies an adverse shock to the supply of crime, and so criminal 
activity is reduced.

As an unintended consequence, however, a demand for money laundering services is created. These services - broadly defined as financial services conducted "to conceal or disguise the nature, location, source, ownership or control" 1 of money - aim: to mask the true origin of funds; to subvert the 'crime-stopping' efforts of the state; and to make it possible to invest or consume the proceeds of crime. According to the consensus of estimates reported by the International Monetary Fund (IMF), between 2\% and $5 \%$ of the world GDP is currently involved in such services (IMF 2004) and, unintended as the very existence of this market may be, this is a figure of tremendous significance. For innocuous as the term 'money laundering' may sound, the presence of a relatively large and strong money laundering market has potentially devastating consequences. An active money laundering market will, for example, distort prices, consumption, saving and investment rates; it will increase the volatility of import/export levels, the demand for money, interest and exchange rates, as well as the availability of credit (Unger, 2007).

In the short run, the existence of a money laundering market will thus undermine the legitimate economy, but as money laundering takes root, the consequences become increasingly dire. In the long term money laundering endangers the survival of the financial sector - not only because of the risk it poses in terms of solvability and liquidity, but in terms of reputation and profitability - which, in turn, threatens the continuance of foreign direct investment (FDI) flows into the country, and denies it an instrument for growth. Furthermore, money laundering is seen to act as a multiplier for crime, corruption, bribery and terrorism which, at its worst, can undermine both the democratic institutions of the state and the foreign policy objectives of its people (Unger, 2007). In the long term, money laundering can thus be seen to poses a serious and even existential threat to the state, and for this reason it must be tackled.

Supplying the market for money laundering is, however, quite clearly profitable. Persecuted for their anti-social actions, criminals are forced by the distinction in the substitutability of money to 'invest' their resources with money launderers for far less than the international rate on legal capital. Research suggests that rates of $5-10 \%$ are routine. The archetypal Hollywood gangster, who 'cleans' his money at roulette, will prefer to play black and red at the same time, and if addicted to gambling, run the risk of interest rates as high as $50 \%$ (Unger, 2007). In a world where no "big bills [are] left on the side walk" (Olson, 1996), an enterprising arbitrageur will always be willing to capitalise on this interest differential, and so the attraction to money laundering will remain constant. The costs incurred by

\footnotetext{
${ }^{1}$ See Stages of the Money Laundering Process, A Report to Congress in Accordance with 356(c) of the USA PATRIOT Act, December 2002.
} 
this enterprising arbitrageur, however, will vary, and will depend directly upon the costs of circumventing anti-money laundering (AML) regulation. As such, the money launders' costs will be directly proportional both to the levels of financial transparency, and to the levels of anti-money laundering (AML) regulation, and as these are directly set by government policy, government can be seen to indirectly control the supply of national money laundering services.

If government controls the levels of money laundering, and if crime is, on balance, destructive to the society, why then, we must ask, is the money laundering market tolerated? In this paper we seek to answer this simple question, and to explain the variance with which AML policy is pursued. In Section Two we begin by overviewing some of the previous literature on this topic, and then introduce a new and simple model of AML competition in Section Three. This model focuses on the differences in country size as the explanatory mechanism for the variation in AML regimes, and explores the incentives associated with financial transparency. It suggests, in essence, that because smaller economies are better able to insulate themselves from the costs of crime, smaller countries therefore bear a smaller share of the total costs relative to the potential benefits of investment that money laundering offers, and so have a higher incentive to tolerate the practice compared to their larger neighbours. The implications of this are then explored in the Section Four, after which Section Five concludes the discussion by summarising the main findings, and drawing implications.

\section{Endogenous AML Policy}

Much of the recent literature on anti-money laundering (AML) policy considers the trade-offs that rational and well-informed policy-makers face when seeking to serve their national interest. Currently, however, the literature considers either heterogeneities between countries, or the strategic interaction between policy-makers. The goal of the model which we present attempts to analyse both of these factors simultaneously, and in a simple setting.

Masicandaro and Portolano (2004), for example, consider the rational behaviour of a single policy-maker. As in our model, government can potentially draw financial benefits from launderers, but faces the costs of increased crime, potential sanctions and a loss of international reputation from doing so. The authors argue that the extent of these costs is not certain, and hence adopt an expected utility framework. They derive comparative statics results for individual countries that also hold in our model, such as greater laxity when crime costs are low. Crucially, Masicandaro and Portolano (2004) consider heterogeneity between countries regarding sanction probabilities and crime costs. They do not, however, focus on strategic interaction 
between policy-makers; the partial equilibrium nature of the approach is also evident in the fact that, for example, benefits from laundering are taken as given by individual jurisdictions.

Unger and Rawlings (2008), on the other hand, focus on strategic interaction of policy-makers but with homogenous countries. Their framework simultaneous-move Cournot competition - follows Sinn (2004), and is very similar to our set-up, as described below. Unger and Rawlings consider far richer interactions than we do - such as, for example, sequential-move games in which a country "breaks out" of an international agreement - but at the limitation of abstracting from heterogeneous costs invariably faced by different policy-makers.

\section{Modelling Transnational AML Policy}

\subsection{The Criminal Market}

In our framework, criminals are driven by the profit motive, and furthermore, these profits can only be consumed once they have been laundered. This brings out the point that money laundering is an essential input to crime production: without laundering, profits cannot be recouped, and the incentive to produce crime is removed. Our model reflects this by adding money laundering directly to a Leontief fixed-proportions production function: ${ }^{2}$

$$
x_{c}=\min \left[l, x_{l}\right]
$$

Here $l$ denotes a composite input ("labour"), and $x_{l}$ the units of money laundering available. Producing a single unit of the criminal good thus requires one unit of the composite input, and one of the laundering input under the most efficient production schedule. The cost function of the criminal is thus given by

$$
c\left(x_{c}\right)=\left(w+p_{l}\right) x_{c}
$$

where $w$ denotes wages, $p_{l}$ the price of laundering.

Aggregating over a large number of price-taking criminals, we find the industry supply function to be:

$$
x_{c}^{s}\left(p_{c}\right)=\left\{\begin{array}{lll}
\infty & \text { if } & p_{c}>w+p_{l} \\
{[0 . . \infty]} & \text { if } & p_{c}=w+p_{l} \\
0 & \text { if } & p_{c}<w+p_{l}
\end{array}\right.
$$

with $p_{c}$ the price of crime.

\footnotetext{
${ }^{2}$ The assumption here is that there is a fixed one-to-one ratio between money laundering and the real assets that the proceeds of this is used to buy.
} 
It is apparent that the supply function is perfectly elastic. That is, the only price consistent with finite and non-zero criminal output is $p_{c}=w+p_{l}$.

Demand for the criminal good is assumed to be downwards-sloping, and more specifically a linear decreasing function of price. For notational simplicity, we set the slope to unity, and therefore let world demand for the criminal good be equal to:

$$
x_{c}^{d}\left(p_{c}\right)=A-p_{c}
$$

with $A$ a constant.

Moreover, we assume that each individual consumes the same amount of the criminal good. This would occur, for example, if each agent had quasilinear preferences and consumed at an interior point. In this setting it is then evident that the share of crime demand of a given country is proportional to its relative population size:

$$
x_{c, i}^{d}\left(p_{c}\right)=s_{i}\left(A-p_{c}\right)
$$

Substituting the industry supply function (3) into national demand gives us an expression for the national equilibrium crime level:

$$
q_{c}^{*}=s_{i}\left(A-\left[w+p_{l}\right]\right)
$$

Total crime is increasing in country size (which increases the strength of demand), decreasing in the criminal's wage and laundering cost, as expected.

As noted, cost-minimising production of the criminal good requires that one unit of the laundering input is used for each unit that is produced. Thus we have have $q_{c}^{*}=q_{l}^{*}$, and the equation above reflects the factor demand for the laundering input.

Total revenue in the laundering market is thus given by

$$
R_{l, i}\left(q_{l} ; \bullet\right)=q_{l}\left[A-w-\frac{q_{l}}{s_{i}}\right]
$$

We assume that the government can capture this revenue, either directly or indirectly. It is precisely this revenue that creates the incentive to tolerate crime - for revenue can partly offset the welfare created by crime.

Criminal goods are presumably illegal because the externalities associated with their production and consumption outweigh the surplus enjoyed by the parties to the exchange. We capture this net social cost of crime with a function $T(\bullet)$, and assume this cost to be a proportional to the level of crime:

$$
T\left(q_{c, i}\right)=c \times q_{c, i}
$$

These costs accrue only within the country in which the criminal good is consumed. 


\subsection{The Closed Economy}

The policy-maker's objective is to choose the optimal degree of anti-money laundering (AML) policy laxity, trading off the benefit of revenue against the social cost of increased crime. Formally stated, her problem (after rearranging the conditional factor demand) is:

$$
\max \phi\left(q_{i}\right)=R\left(q_{l, i}\right)-T\left(q_{l, i}\right)
$$

Substituting and maximising, we find

$$
q_{l, i}^{*}=\frac{s_{i}}{2} \times(A-w-c)
$$

Thus our very simple model suggests that, in the absence of international interaction effects, government policy will permit crime per person to rise as $N_{i}$ slowly grows. This is because a larger number of people in the country lead to an expansion of the demand for the criminal good, and hence a more favourable trade-off between allowing money laundering and the social cost of crime.

\subsection{The Open Economy}

Suppose now that we have $k$ countries, with population shares $s_{1}, s_{2} \ldots s_{k}$ respectively. Each country is sovereign, and so sets a policy on money laundering laxity - that is, on the quantity of laundering that will be permitted within its jurisdiction - labelled $q_{l, i}$. Because laundering services are internationally tradable, this policy has spill-over effects on other jurisdictions. In particular, much of the laundering permitted by a small country will typically be used to support crime that takes place abroad, because said country only contributes a small part to world crime consumption. This causal mechanism is fundamental to our simple model of transnational competition for criminal money.

The model is developed in analogy with a classic model in industrial organization - the Cournot model - expanded to cover heterogenous firms/countries. We are looking for a Nash equilibrium in strategies $\left(q_{1} \ldots q_{k}\right)$, in which no state can change its laundering policy unilaterally without worsening its payoff.

Let $Q^{-i}$ denote the cumulative output of all countries except $i$. Then the country's problem is to

$$
\max S W F_{i}=\left[A-w-\left(Q^{-i}+q_{l, i}\right)\right] q_{l, i}-T\left[s_{i}\left(Q^{-i}+q_{l, i}\right)\right]
$$

Taking the policies of other countries as given, maximising this expression yields the optimal laundering output

$$
q_{i}^{*}=\frac{A-w-s_{i} \times c-Q^{-i}}{2}
$$


Thus, the larger the country, the higher its marginal cost of laundering - creating relatively more crime at home than abroad - and the lower its laundering output, all other things equal.

Furthermore, as is common in Cournot models, anti-money laundering policies (AML) are seen to be strategic substitutes. That is, if one country relaxes its AML policy, other countries will tend to tighten theirs. This occurs because the latter find that the ceteris paribus lower price of laundering yields them a less favourable trade-off of revenue for crime.

For each country of the $K$ countries, one such first order condition is obtained. Solving them simultaneously yields the Nash equilibrium solution of world laundering output (cf. Varian and Bergstrom 1985):

$$
2 Q=K(A-w)-K * Q-Q-1
$$

Rearranging:

$$
Q=\frac{K(A-w)-1}{K+3}
$$

Total world money laundering is therefore not affected by the size distribution of countries. In other words, the existence of small countries does not necessarily change the amount of world laundering, but merely its distribution between countries.

To summarise, the simple model of transnational competition for criminal money yields three key results:

- Countries exert a laundering externality on each other, because they fail to take into account the cost of lax financial regulation to other countries when setting their AML policy goals.

- We derived an endogenous 'Seychelles effect', resulting from the fact that small countries are low-cost producers of money laundering: they need to bear only a small part of the social cost they generate.

- However, in this model we note the irrelevance of the country size distribution to world laundering output. This results from the fact that small countries are seen to out-compete their larger counterparts in the ML market.

\section{Discussion}

Our model thus suggests that, in a closed economy, the state will be forced to 'internalise' the total costs of crime and, as a result, it will be forced to suffer the (negative) net consequence of criminal activity. Accordingly, crime prevention will quickly becomes a high policy priority for the government of the closed economy, and financial transparency - being the only policy 
instrument permitted by our model in achieving this end - will be set at a high level.

In the more realistic context of an open economy, however, the fact that crime is both organised and globalised means that the incident and effect of crime can be separated from the positive cash flows they create. Total social costs can be divided across countries - irrelevant of incident, cause and effect - and each country's domestic arbitrageurs can therefore hope to profit from the crimes in other jurisdictions. In this context Pecunia non olet ${ }^{3}$ means that government will then be pressurised and incentivised to lower its regulatory standards, and to attract investment. Moving from the closed economy, openness and globalisation are thus seen to erode the incentive for higher levels of financial transparency, simply because countries with lower standards will enjoy high net investment. As a consequence, we will observe a "beggar-thy-neighbour" policy in relation to the competition for criminal monies, along with an international 'regulatory race to the bottom' (Sinn, 2004), as well as the toleration of a sub-optimal level of crime. Only a single country is necessary to breaks the "chain of accountability" and to provide a safe haven for criminals and so, given the incentives, we can conclude that unless anti-crime policy becomes a transnational issue with a collusive, multinational response, justice can and will not be served in the context of an open economy.

The story, however, does not end there. In an open economy, low standards of financial transparency do not merely affect the market for money laundering, but will, in fact, affect all sectors of the economy equally. Poor financial standards are likely, for example, to encourage the diversion of assets in businesses, to lead to poor supervision of companies (and hence reduce the quality of governance), and to encourage directly unproductive, profit-seeking activities. Because in our framework the state has only a single policy instrument with which to fight crime - namely the level of transparency - these effects are the inescapable consequence of it's effort to tolerate crime and court the profits from money laundering. As a result, we observe a significant trade-off in the decision to tolerate money laundering.

We suggest then that countries with a large legal-economy sector in absolute terms will be most affected by low financial standards, and will have the most to loose by dropping them, and so the costs of tolerating money laundering for small economies vis-a-vis their larger counterparts are reduced. Countries with a large legitimate economy can therefore be expected to avoid the money laundering market, while smaller undeveloped economies will be seen to embrace it, and this finding, we believe, provides an explanation for the variance with which AML policy is pursued. There will, of course, be exceptions to this generalised rule ${ }^{4}$, but by this reasoning, we

\footnotetext{
3"Money does not stink"

${ }^{4}$ According to the Financial Times (May 1st, 2007) "[m]any US states, including
} 
would only expect to observe money laundering amongst small, developing countries.

And the Financial Action Task Force on Money Laundering (FATF) agrees with this conclusion. The 2000/2001 list of 'Non-Cooperative Countries and Territories' (NCCT) identifies a number of countries which clearly tolerated money laundering, and clearly cater to the needs of the criminal networks. In its 2000 report, the Bahamas, the Cayman Islands, the Cook Islands, Dominica, Israel, Lebanon, Liechtenstein, the Marshall Islands, Nauru, Niue, Panama, Philippines, Russia, St. Kitts \& Nevis and St. Vincent \& the Grenadines were identified as NCCTs, and in 2001 Egypt, Grenada, Guatemala, Hungary, Indonesia, Myanmar, Nigeria, and Ukraine were added to the list, and labeled as having "deficiencies" in their AML regimes (FATF 2002). And while the usefulness of this list is often criticised for being 'politically dead' - because countries may, for example, be removed for 'apparently' rather than 'actually' complying with AML best-practice (Unger \& Ferwerda, 2008; Masciandaro 2005) - the NCCT 'blacklist' illustrates: firstly, that non-cooperative countries exist, and that there is indeed a variance in international AML regimes; and secondly, that for a large part, the offending nations tend to be smaller countries, relatively poorer, and typically geographically remote, island nations. The 'gravity model of transnational money laundering' developed by Walker (1995) clearly reflects these findings and points decisively to the islands of the Pacific/Caribbean as being centres for international money laundering, as does Unger (2007) in a recent re-estimation of the model, and Morris-Cotterill (2001) in a more general study of the money laundering industry.

It should be noted, however, that these findings do not mean that the "giants [don't] wash more" (Unger 2007, p. 79). As Unger (2007, p. 191) suggests "it is not [the] small states like Liechtenstein, Anguilla and Bermuda... [but] large, industrialised OECD economies that are the main conduits for laundering money". Walker (1999), for example, estimates that a staggering $46.3 \%$ of the world's money laundering originates in the Unites States, and as Unger (2006) shows, Luxembourg - home to the European Court of Justice and the secretariat of the European Parliament - is the most attractive destination in the world (Unger 2007, p77).

What we have shown, however, is that there is a large and important distinction between intended and unintended money laundering in terms of incentives, and that the list of offenders which both produce are quite markedly different. We recognise that unintended money laundering is prob-

Delaware and Nevada ... [along with] many industrialised countries [intentionally] reduce transparency. Switzerland limits exchange of tax information to cases of fraud [while] Hong Kong and Singapore limit information exchange to cases where they have a domestic interest". Switzerland, Hong Kong and Singapore, despite having large legitimate economies, earn a significant income from their status as financial tax havens, and enjoy this status for historical reasons. As a result, these countries act as outliers to our rule. 
ably far larger in the US, Switzerland and the UK then it is in most of the Pacific/Caribbean put together, but the key here is that this is unintended money laundering, which arises out of the complexity and scale of the financial systems that these countries operate. We have shown that the incentives for the state sponsored toleration of money launder simply do not exist amongst the larger and more developed countries.

Our model suggests, however, that small, open and developing economies have a very strong incentive to pursue a 'Seychelles strategies' (Unger and Rawlings, 2008); that is, to promote intended money laundering, to flaunt international anti-money laundering agreements, to participate in the international deregulatory race to the bottom, to free-ride on the crime-stopping efforts of the developed nations, and to attract investment almost at any cost. Therefore, while the small island economy may - potentially at least - represent only a small share of the total money laundering market, it will have a far higher contribution proportionate to its economic importance. For these reasons, we believe that the "Seychelles strategy" of inviting capital under the guarantee of immunity from prosecution (Unger and Rawlings, 2008 ) is far more dangerous to both the rule of law and the legitimate economy of other territories, and claim that such policies must therefore merit far stronger international attention in the future.

\section{Conclusions}

This paper has argued that the criminalisation of crime has created a market for laundering services which conceals the sources of criminal profits, and hence allows the illegitimate proceeds of crime to be used in the 'clean' or 'white' economy. Because criminals are profit-motivated, the availability of laundering services is a key determinant of degree criminal output in a society. Section 3 shows in a simple model that in a closed economy, the government can successfully trade-off the revenue gains that can be obtained from tolerating laundering against the social cost of crime, and thereby maximise social welfare.

In an open economy, however, this result no longer holds. Geographically, the location of crime and the laundering of its profits can easily be separated. Criminals need only find the weakest link to break the 'chain of accountability', to have their funds "cleared". In our simple model, the agents were identical and the national consumption of the criminal good was thus proportional to the population size of the country. Small countries can thus tolerate more money laundering, thereby obtaining the full benefits of receiving revenue but needing to bear only a relatively small share of the social costs that they create. Such policy moves have become known, since Unger and Rawlings (2008), as "Seychelles strategies".

It it was also apparent in our multi-country model, however, that the 
existence of countries with lax financial regulation, such as the Seychelles, does not necessarily lead to an increase in world crime output. This is because larger countries are "competed out" of the market by their smaller counter-parts. If the cost of crime are linear, this crowding-out effect offsets exactly the increased output of small countries; the Nash equilibrium is thus independent of the size distribution of countries. We do not wish to suggest that this finding is descriptively accurate, but note that such potential fallacies of aggregation need to be addressed in future research on the transnational dimension of AML policy.

Data limitations loom large in the economic analysis of AML policy, and for this reason, we do not conduct formal econometric tests in this paper. However, and as we noted above, the basic results of our discussion are consistent with previous empirical research, and also serve to complement earlier theoretical insights. In spite of this, it must be re-iterated that the 'economics of money laundering' is still an emerging field, and so research on estimates of money laundering will, in our view, be highly relevant in guiding and supporting future modelling exercises.

\section{References}

Anderson, D. (1999) The Aggregate Burden of Crime, in Journal of Law and Economics, Vol. 42, No. 2, pp. 611-641.

Audit Commission (1999) Safety in Numbers, Promoting Community Safety. Abingdon: Audit Commission Publications.

Beccaria, C. (1992) 'On Crime and Punishment', Branden Books

Blumstein, A. \& D. Nagin (1977) 'The Deterrent Effect of Legal Sanctions on Draft Evasion', Stanford Law Review 28, p.241

Brand, S. \& R. Price (2000) 'The Economic and Social Costs of Crime', Home Office Research Study 217

Cooter, R. \& T. Ulen (2004) 'Law and Economics', 4th Edition, Pearson Addison Wesley

Ehrlich, I., (1973) 'Participation in Illegal Activities: A Theoretical and Empirical Investigation', Journal of Political Economy 81, p.521

Economist, the (2007) 'Offshore Finance: Places in the Sun', Feb 22nd 2007, print edition 
Federal Bureau of Investigation, (1997) 'Crime in the United States', Uniform Crime Reports, Washington, DC: U.S. Department of Justice (Released September 28, 1997)

Ferbrache, M.D., (2001) 'Offshore Financial Centres', FBI Law Enforcement Bulletin, 70, p. 10

Financial Action Task Force, (2000) 'Annual Review of Non-Cooperative Countries and Territories', available at http://www.fatf-gafi.org/dataoecd/56/43/33921824.pdf

Financial Action Task Force, (2001) 'Annual Review of Non-Cooperative Countries and Territories', available at http://www.fatf-gafi.org/dataoecd/4/32/33922320.pdf

Financial Action Task Force, (2006) 'Annual Review of Non-Cooperative Countries and Territories', available at http://www.fatf-gafi.org/dataoecd/41/26/34988035.pdf

Financial Times, The (2007), 'Financial Standards Come Under Fire', by Vanessa Houlder, published May 12007

Freedman, M., (2006) 'Fantasy Island', Forbes, 177, p. 90

Hobbes, T., (1982) 'Leviathan', Penguin Classics International

International Monetary Fund (2004) 'The IMF and the Fight Against Money Laundering and the Financing of Terrorism, A Fact Sheet', September 2004

Leonard, D., (2001) 'Cyprus', Europe, 407, p.3

Masciandaro, D., (2004) 'Global Financial Crime: Terrorism, Money Laundering, and Off Shore Centres', Ashgate Publishing

Masciandaro, D., (2005) 'False and Reluctant Friends? National Money Laundering Regulation, International Compliance and Non-Cooperative Countries', European Journal of Law and Economics, 20, p. 17-30

Masciandaro, D. and A. Portolano (2003) 'It takes Two to Tango: International Financial Regulation and Offshore Centres, Journal of Money Laundering Control, 6,4.

Masciandaro, D., E. Takats \& B. Unger (2007) 'Black Finance: The Economics of Money Laundering', Edward Elgar 
Morris-Cotterill, N., (2001) 'Money Laundering', Foreign Policy 124, p.16

Olson, M., (1996) 'Big Bills Left on the Sidewalk: Why Some Nations are Rich, and Others Poor', Journal of Economic Perspectives, Vol. 10, No. 2, pp. $3-24$

Ormerod, D., (2005) 'Smith \& Hogan Criminal Law', 11th Edition, Oxford University Press

Reuter, P. and E. M. Truman (2004) 'Chasing Dirty Money - The Fight against Money Laundering', Institute for International Economics, Washington DC ing

Sinn, H.W., (2004) 'The New Systems Competition', Blackwell Publish-

Takats, E. (2007) 'A Theory of "Crying Wolf: The Economics of Money Laundering Enforcemnet', IMF Working Paper WP/07/81

Unger, B. and J. Ferwerda (2008), 'Regulating Money Laundering and Tax Havens: The Role of Blacklisting, '(Re)Regulation in the Wake of Neoliberalism, Consequences of Three Decades of Privatization and Market Liberalization' Conference Paper, (May 15th, 2008).

Unger, B. and G. Rawlings (2008) 'Competing for Criminal Money', Global Business and Economics Review, Vol 10, No.3, 2008

Unger, B., (2007) 'The Scale and Impact of Money Laundering', Edward Elgar Publishing

Varian, H. and T. Bergstrom (1985), 'When Are Nash Equilibria Independent of the Distribution of Agents' Characteristics?', The Review of Economic Studies, Vol. 52, No. 4, pp. 715-718

Wilson, J.Q. and A. Abrahamse (1992) 'Does Crime Pay?' Justice Quarterly, 9 , p. 359

Wolpin, K., (1978) 'An Economic Analysis of Crime and Punishment in England and Walses 1894-1967', Journal of Political Economy, 86, p. 815 